\title{
The Kinectics and Inhibition Properties of Partially Purified Glutathione Transferase from the Head of Palm Weevil (Rynchophorus Phoenicis) Larva
}

\author{
Oyewole O. Nather ${ }^{1}$, Falodun A. Emmanuel ${ }^{2}$ \\ Department of Science Technology, Federal Polytechnic Ado Ekiti, Ekiti State
}

\begin{abstract}
An insect cytosolic glutathione transferase (GST) was partially purified from the head of palm weevil (Rynchophorous phoenicis) larvae using DEAE- cellulose ion exchange chromatography. The purified GST showed conjugating activity readily with 1chloro- 2, 4-dinitrobenzene (CDNB) and the activity was inhibited by an insecticide 2, 2-dichloroethenyl dimethyl phosphate (DDVP). Palm weevil GST displayed a Michealian behavior at low $(0.1-1.0 \mathrm{mM})$ substrate concentration. $\mathrm{K}_{m}{ }^{(G S H)}$, Vmax was calculated to be 0.70 $\mathrm{mM}$ and $40.98 \mu \mathrm{mol} / \mathrm{min} / \mathrm{mg}$ whereas $K_{m}$ and $V_{\max }{ }^{(C D N B)}$ was $33.2 \mu \mathrm{mol} / \mathrm{min} / \mathrm{mg}$ and1.55 $\mathrm{mM}$ respectively. GST from the head of palm weevil larva probabily possesses ability to catalyse external toxic substances and may be implicated in GST-based resistance.
\end{abstract}

Keywords: Kinectics, Inhibition, glutathione transferase, Rynchophorus phoenicis.

\section{Introduction}

Glutathione S-transferases (GSTs; E.C. 2.5.1.18) are a large family of multifunctional enzymes found ubiquitously in aerobic organisms (Clark, 1990). The majority of studies on insect GSTs have focused on their role in detoxifying xenobiotic compounds, in particular insecticides and plant allelochemicals and, more recently, their role in mediating oxidative stress responses (Fournier et al., 1992; Ranson et al., 2001; Vontas et al., 2001). Increased GST activity has been detected in strains of insects resistant to organophosphates and organochlorines (Fournier et al., 1992). and this enzyme family has recently been implicated in resistance to pyrethroid insecticides (Kostaropoulos et al., 2001; Vontas et al., 2001). What's more, GST-based resistance to insecticides was described to be facilitated by the increase in the level of expression of one or more GSTs.

The African black palm weevil (Rhynchophorus phoenicis) is a species of snout beetle.At its developmental stage palm weevil larvae can excarbate holes in the trunk of a palm trees up to a meter long thereby weakening and eventually killing the host plant, as a result,the weevil is considered as a major pest in palm plantations including coconut palm,date palm and oil palm. The adaptation of this insect pest to its host environment might be due to presence of GST in the insect particularly at the larva stage (Bozbuga and Hazir,2008). This study therefore seeks to determine the kinectics and inhibition of partially purified Glutathione transferase from the head of palm weevil (Rynchophorus phoenicis) larva

\section{Materials and Methods}

Experimental insects

The Palm weevil larva used for this work was obtained from infected palm tree in Iye area of Ekiti State,Nigeria.The larvae were randomly selected for measuring the enzyme activity.

\section{Chemicals}

Reduced glutathione (GSH), 1-chloro-2,4-dinitrobenzene (CDNB),2,2-dichloroethenyl dimethyl phosphate(DDVP) ethylenediaminetetraacetic acid (EDTA), bovine serum albumin (BSA) and DEAE-Sephadex were purchased from Sigma Reduced glutathione (GSH) was used as a distilled water solution. 1-chloro-2, 4-dinitrobenzene (CDNB) solution was prepared in ethanol. Other chemicals were of the highest purity commercially available.

\section{Dissection of larvae}

The larvae were kept in the freezer to demobilize the organism in order for the dissection to be possible and easy. After freezing, the larva was removed and placed on a board laid with aluminium foil and dissected using dissecting kits - forceps, knife, e.t.c. The dissected larva was then separated into three fractions; Head, Gut and the Body Tissue, based on their respective grouping. The head was well labelled and were kept in the research refrigerator until required

\section{Preparation of crude extract}

Head of palm weevil larva was homogenised at $4^{0} \mathrm{C}$ in a ratio of $1: 4(\mathrm{w} / \mathrm{v})$ with $100 \mathrm{mM}$ potassium phosphate buffer, $\mathrm{pH}$ 7.2. The homogenate was centrifuged at $10,000 \mathrm{~g}$ for 10 min and the pellet was discarded. The supernatant was filtered through glass wool and the cytosolic glutathione Stransferase was obtained. The enzyme solution was stored in the cold at $-20^{\circ} \mathrm{C}$ until needed. ( Cohen,1987).

\section{Purification of GST by glutathione ion exchange chromatography \\ The crude extract was applied to a DEAE-Sephadex $\mathrm{A}_{50}$ ion exchange column $(20 \times 15 \mathrm{~cm})$ previously equilibrated with $20 \mathrm{mM}$ phosphate buffer, $\mathrm{pH} 7.2$ and the protein fraction was eluted with stepwise increase molarity of phosphate buffer $\mathrm{pH} 7.2(0,02-0.2 \mathrm{M})$. The active were pooled and stored at $-20^{\circ} \mathrm{C}$ ( Cohen, 1987).}

\section{Enzyme Assay}

GST catalytic activity was determined spectrophotommetrically with the aromatic substrate 1chloro-2,4 dinitobenzene(CDNB) by monitoring the change 


\section{International Journal of Science and Research (IJSR) \\ ISSN (Online): 2319-7064 \\ Index Copernicus Value (2015): 78.96 | Impact Factor (2015): 6.391}

in absorbance, due to thioeter formation at $340 \mathrm{~nm}$ and $25^{\circ} \mathrm{C}$ as described by(Habig et al; 1974).The assay mixture contained in a total volume of $1 \mathrm{ml}$. $0.1 \mathrm{M}$ potassium phosphate buffer at $\mathrm{pH} 7.4,1 \mathrm{mM}$ CDNB in ethanol,1 $\mathrm{mM}$ GSH and the enzyme solution.the increase of absorbance at $340 \mathrm{~nm}$ of the complete assay reaction was monitored against a control containing buffer instead of the enzyme and treated similarly. The product extinction coeficient was taken to be $9.6 \mathrm{mM}^{-1}$ defined as the amount of enzyme which catalyses the formation of $1 \mu \mathrm{mol} / \mathrm{min} / \mathrm{mg}$ protein.Protein concentration was determined by the method of Using bovine serum albumin(BSA) as a standard.(Lowry, 1971)

\section{Kinectic analysis}

The kinetic parameters $\mathrm{Km}$ and Vmax were determined for purified palmweevil GST using reduced glutathione and CDNB as substrates. When CDNB constants were measured, the GSH concentration was held at $1 \mathrm{mM}$ while the CDNB concentration was varied from 0.1 to $1.0 \mathrm{mM}$. When GSH constants were measured, the CDNB concentration was held at $1 \mathrm{mM}$ while the GSH concentration was varied from 0.1 to $1 \mathrm{mM}$. Maximal velocity (Vmax) and Michaelis constant $(\mathrm{Km})$ values for each substrate were calculated from Lineweaver Burk double reciprocal plot

\section{Protein content determination}

Protein contentsof theenzyme homogenate were determined according to the method of using bovine serum albumin as the standard. The measurement was performed with the wavelength of $340 \mathrm{~nm}$ (Lowry, 1971).

\section{Result}

\section{Purification of GST}

Two major protein peaks were obtained in the flow through fractions while two minors peak were obseved to bind to the column after washing the column with $\mathrm{NaCl}$ solution. These were done by reading each fractions at the absorbance of $280 \mathrm{~nm}$. Estimation of GST in all the fraction showed two major activity peaks (Fig 4).

\section{Kinetic of palm weevil GST}

The kinectic properties of partially purified GST from head of a palm weevil larva head were studied.Line weaver burk plot of enzyme catalysed reactions with varying concentrations of glutathione $(0.1-1 \mathrm{mM})$ at a fixed concentration of CDNB (1 $\mathrm{mM})$ or glutathione $(1 \mathrm{mM})$ respectively as shown in fig5a and $5 \mathrm{~b}$ and the $\mathrm{Km}$ and $\mathrm{Vmax}$ were calculated as shown in table $1 . \mathrm{Km}^{(\mathrm{GSH})}, \mathrm{V}_{\mathrm{Max}}$ was calculated to be $(0.70 \mathrm{mM}$ and $40.9 \mu \mathrm{mol} / \mathrm{min} / \mathrm{mg})$ whereas $\mathrm{Km}$ and $\mathrm{Vmax}{ }^{(\mathrm{CDNB})}$ was $1.55 \mathrm{mM}$ and $33.2 \mu \mathrm{mol} / \mathrm{min} / \mathrm{mg}$

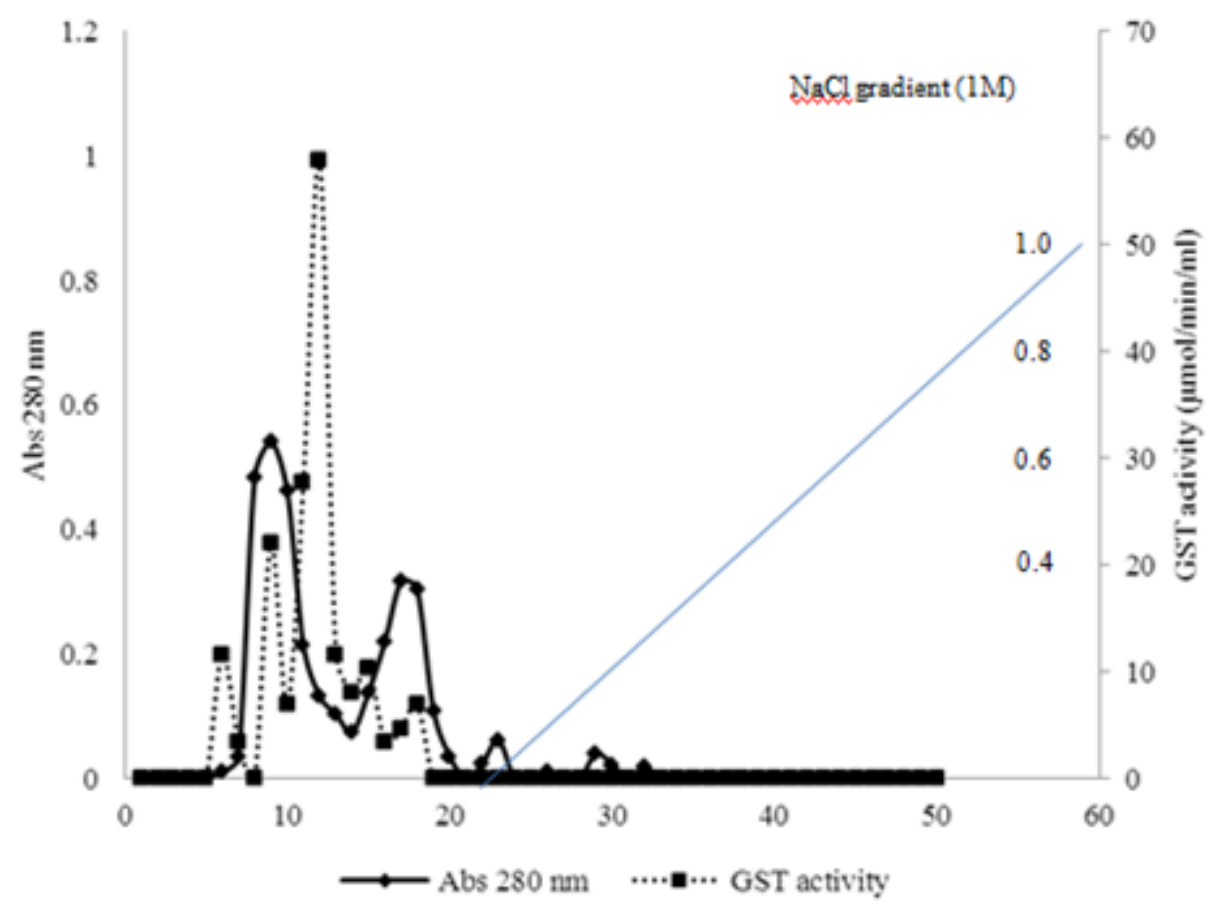

Figure 4: Elution profile of glutathione transferase from the head of palm weevil (Ryhncophorus phoenicis) larva using ion exchang chromatography. Crude enzyme was applied on CMC-cellulose column $(1.5 \times 20 \mathrm{~cm})$ previously equilibrated with $20 \mathrm{mM}$ phosphate buffer, $\mathrm{pH} 7.2$ containing $1 \mathrm{mM}$ EDTA and $1 \mathrm{mM}$ mercaptoethanol. $5 \mathrm{ml}$ fractions were collected at a flow rate of $10 \mathrm{ml} / \mathrm{h}$ 


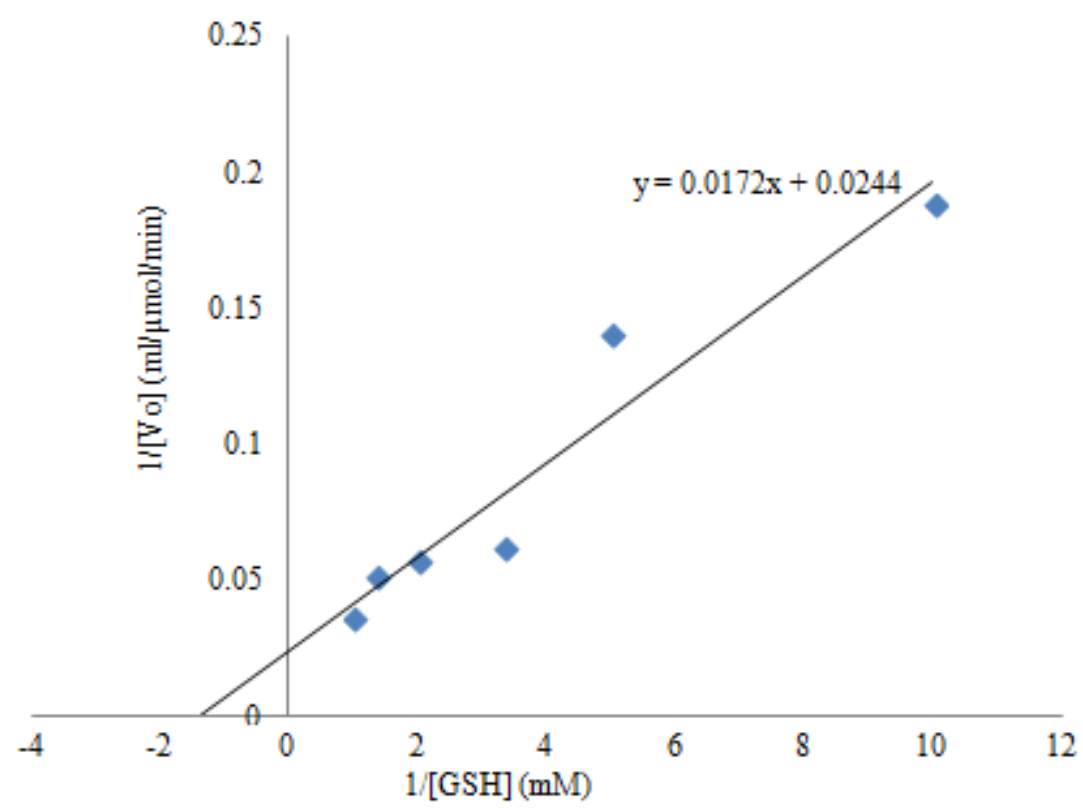

Figure 5A: Line-weaver Burk plot of partially purified glutathione transferase from the head of palm weevil.

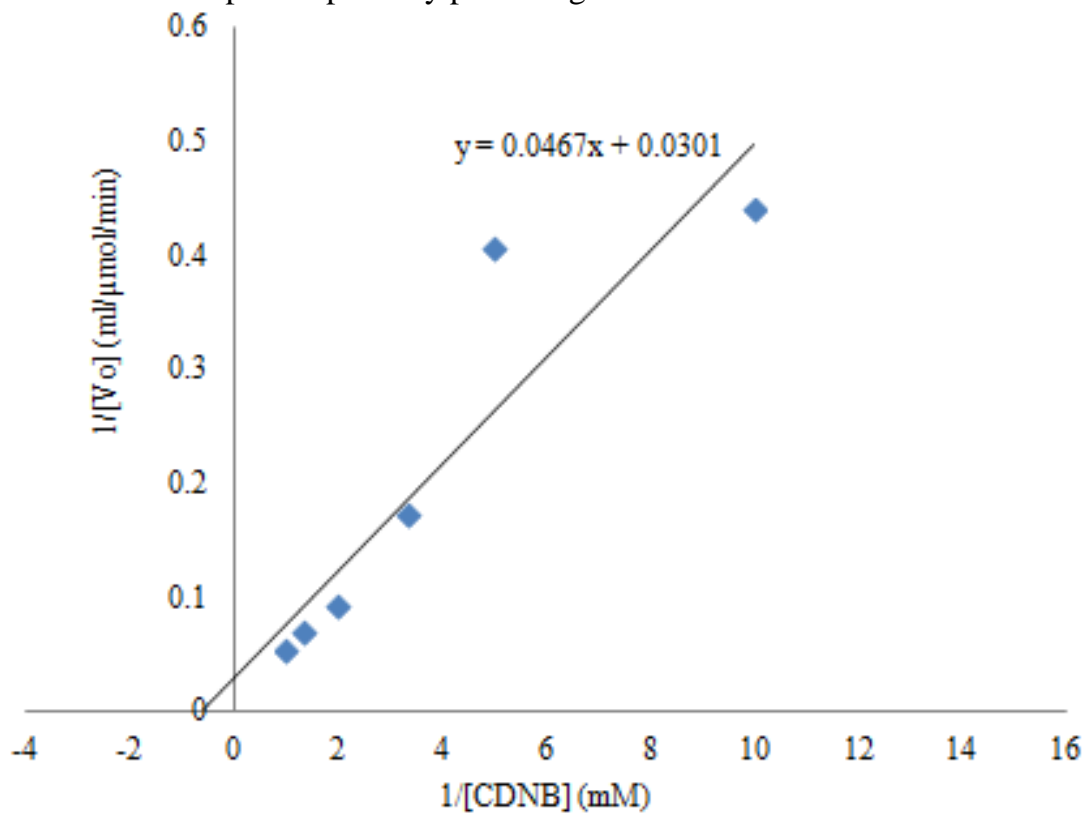

Figure 5B: Line-weaver Burk plot of partially purified glutathione transferase from the head of palm weevil.

Table 1: Kinetic parameters of partially purified GST from head of palm weevil

\begin{tabular}{|c|c|c|}
\hline Substrate & $\mathrm{K}_{\mathrm{M}}(\mathrm{mM})$ & $\mathrm{V}_{\mathrm{MAX}}(\mu \mathrm{mol} / \mathrm{min} / \mathrm{mg})$ \\
\hline CDNB & 1.55 & 33.22 \\
\hline GSH & 0.70 & 40.98 \\
\hline
\end{tabular}

\section{Inhibition Studies}

The result of GST inhibition with a known insecticides 2, 2dichloroethenyl dimethyl phosphate (DDVP) is shown in Table 2.The strongest of inhibition 37\% was observed with DDVP in absence of CDNB and the weakest of $61.45 \%$ with prescence of insecticides 2,2-dicloroethenyl dimethyl phosphate (DDVP) CDNB, Enzyme and GSH,The performed inhibition assay shows that the activity of palm weevil larva GST was inhibited to various extent by 2,2dicloroethenyl dimethyl phosphate (DDVP)
Table 2: In vitro inhibition of partially purified palm weevil larva GST

\begin{tabular}{|l|l|c|}
\hline Set-up (inhibition assay) & \multicolumn{1}{|c|}{$\begin{array}{c}\text { Activity } \\
(\mu \text { molmin } / m l)\end{array}$} & $\begin{array}{l}\text { Residual } \\
\text { activity (\%) }\end{array}$ \\
\hline Enz+GSH+CDNB & $25.23 \pm 0.14$ & 100 \\
Enz+GSH+DDVP & $9.36 \pm 0.45$ & 37.10 \\
Enz+GSH+DDVP+CDNB & $15.23 \pm 0.29$ & 61.45 \\
\hline
\end{tabular}

\section{Discussion}

Analysis of Lineweaver-burk plot (Table1 and figure 5).provide the information regarding the mode of action of GST in palm weevil larva which was enzymatically characterised with CDNB and GSH as substrates . Km, and Vmax GST from the head of palm weevil larva were comparable to values reported for other insect $\mathrm{GST}_{\mathrm{s}}(\mathrm{Yu}$, 1996). the $K_{m}$ and $V_{m a x}$ from palm weevil larva were higher than other lepidoptoreous insect(Ranson et al., 2001). and most similar to corresponding constant reported in GST

Volume 6 Issue 7, July 2017

\author{
www.ijsr.net
}

Licensed Under Creative Commons Attribution CC BY 


\section{International Journal of Science and Research (IJSR) \\ ISSN (Online): 2319-7064}

Index Copernicus Value (2015): 78.96 | Impact Factor (2015): 6.391

from Bulinus truncates( $\mathrm{Yu}$, 1996). The apparent $\mathrm{K}_{\mathrm{m}}$ values for glutathione and CDNB appeared to be similar, while the apparent $\mathrm{V}_{\max }$ for CDNB was lower than that of glutathione. This suggest that GST of palm weevil larva had a higher affinity for glutathione than for CDNB

The role of insect detoxification enzymes in the metabolism of insecticides, allelochemicals and other xenobiotics is well established (Ranson et al., 2001 ). The table 2 show that GST are present in palm weevil larva of concentrations comparable with those in other insects in vitro, and its sensitive to the inhibitory effect of DDVP. The strongest inhibition of $37.10 \%$ was observed with DDVP in the absence of substrate and $67.10 \%$ in the presence of substrate (CDNB), and this may be due to reaction of DDVP with essential residues related to GSH binding. Most GST have a cysteine residue near the the active site, and modification of this residue alters the binding of GSH as been shown for some vertebrates (Stella et al; 1998). It is possible that DDVP can react with GSH as it does with other thiols ( $\mathrm{Yu}$, 1996 ). to form a conjugate and the result indicated that DDVP can act as a substrate.

\section{Conclusion}

The GSTs in insects are primarily of interest because of their role in insecticide resistance. They are involved in the $\mathrm{O}$ dealkylation or O-dearylation of organophosphorus insecticide. as a secondary mechanism in the detoxification of organophosphate metabolites and in the dehydrochlorination oforganochlorines. This study presented some basic biochemical information of GSTs from palm weevil larva and surely will help in understanding the interaction of GSH with a known insecticide in the presence and absence of enzyme substrate and inhibition of partially purified GST from the head of palm weevil larva.

\section{References}

[1] Bozbuga R and Hazir A. (2008). Pests of the palm (palmae sp.) and date palm(Phoenix dactylifera) determined in Turkey and evaluation of Red palm weevil(Rhynchophorus ferrugineus Oliv) (Coleoptera; Curculionidae). DEPP/EPP.Bulletin, 38: 127-130.

[2] Clark AG (1990). The glutathione S-transferases and resistance to insecticides. In: Hayes JD, Pickett CB, Mantle TJ, editors. Glutathione S-transferases and drug resistance. London: Taylor and Francis. p 369-379

[3] Cohen E (1987). Purification of glutathione Stransferase from the flour beetle Tribolium castaneun. Comp. Biochem. Physio B679.

[4] Fournier D, Bride JM, Poire M, Berge JB, Plapp FW (1992). Insect glutathione S-transferases. Biochemical characteristics of the major forms from houseflies susceptible and resistant to insecticides. J.Biol. Chem. 267: 1840-1845.

[5] Ge J, Singh BR (1996). Physicochemical characterization of glutathione S-transferase purified from oyster, Crassostra virginica. J. Mar. Biotechnol. 4: 150-154.

[6] Habig WH, Pabst MJ, Jakoby WB (1974). Glutathione S-transferases: the first enzymatic step in mercapturic acid formation. J. Biol. Chem. 249: 7130-7139.
[7] Ranson H, Rossiter L, Ortelli F, Jensen B, Wang X, Roth CW, Collins FH, HemingwayV (2001). Identification of a novel class of insect glutathione Stransferases involved in resistance to DDT in the malaria vector Anopheles gambiae. Biochem. J. 359: 295-304.

[8] Stella, L., Caccuri, A.M., Rosato, N., Nicotra, M., Lo Bello, M., DeMatteisi, F., Mazzetti, A.P., Federici, G., Ricci, G., 1998. Flexibility of helix 2 in the human glutathione transferase P1-1.Timeresolved fluorescence spectroscopy. Journal of Biological Chemistry 273, 23267-23273.

[9] Vontas JG, Small GJ, Hemingway J (2001). Glutathione S-transferases as antioxidant defense against confer pyrethroid resistance in Nilaparvata lugens. Biochem. J. 357: 65-72.

[10] Yu JS (1989). Purification and characterization of glutathione transferases from five phytophagous Lepidoptera. Pestic. Biochem. Physiol. 35: 97-105.

Volume 6 Issue 7, July 2017 www.ijsr.net 